\title{
Petrophysical properties of the Mamuniyat Formation for hydrocarbon potentiality in "A" Oil Field, NC115 Concession of Murzuq Basin, Libya
}

\author{
Adel K. Mohamed ${ }^{1,2} \cdot$ Ahmed M. Beshr ${ }^{1,3}$ \\ Received: 9 January 2021 / Accepted: 5 February 2022 / Published online: 2 March 2022 \\ (c) The Author(s) 2022
}

\begin{abstract}
The Mamuniyat sandstones represent the main reservoir in the "A" Oil Field, NC115 Concession, Murzuq Basin of Libya. As a result, the primary objectives of the current work are to evaluate and define the Mamuniyat Formation's petrophysical parameters using well-logging analysis. For this study, the available well-logging data from ten exploratory wells were provided. Several cross-plots were used to evaluate the lithologic constituents and fluid saturations in the form of litho-saturation cross-plots, and their output parameters were fed as inputs for Interactive Petrophysics (IP) software. According to the output results, the Mamuniyat Formation is primarily composed of sandstones with a few shales. These sandstones are generally fine- to coarse-grained, as indicated by the cross-plots, with a coarsening-upward sequence. According to the litho-saturation analysis, the Mamuniyat Formation is primarily oil-bearing with some levels of water-bearing sand. The petrophysical parameters derived from well-logging data agree with those derived from core sample analysis, demonstrating that the Mamuniyat Formation is a good reservoir.
\end{abstract}

Keywords Petrophysical parameters · Litho-saturation · Cross-plot · Mamuniyat · NC115 Concession · Murzuq Basin · Libya

\section{Introduction}

Libya is a country in the Maghreb region, located on the coast of the Mediterranean Sea in northeastern Africa, roughly between longitudes $10^{\circ}$ and $25^{\circ} \mathrm{E}$ and latitudes $20^{\circ}$ and $33^{\circ} \mathrm{N}$. Its mainland covers an area of approximately $1,775,500 \mathrm{~km}^{2}$ and is bordered to the east by Egypt, to the west by Algeria, to the northwest by Tunisia, to the southeast by Sudan, to the south by Chad, and to the southwest

Responsible Editor: Amjad Kallel

Adel K. Mohamed

mohamedemamm79@yahoo.com; adelkamel@mans.edu.eg

Ahmed M. Beshr

beshr@mans.edu.eg

1 Department of Geology, Faculty of Science, Mansoura University, Mansoura 35516, Egypt

2 Faculty of Basic Sciences, New Mansoura University, New Mansoura 35712, Egypt

3 Institute of Geology and Geophysics, Chinese Academy of Sciences, Beijing 100029, China by Niger (Fig. 1). Since the Paleozoic, Libya was exposed to many marine transgressions and regressions, resulting in the deposition of thick sections of a variety of continental and marine sedimentary rocks. Regional tectonic events such as the Caledonian, Hercynian, and Alpine played a significant role in shaping the geological and structural setting of Libya. They resulted in the formation of four major intracratonic basins, Ghadames, Sirt, Murzuq, and Al Kufra, which were separated by intervening uplifts and platforms (Nafusah, Gargaf, Tibesti, and Cyrenaica Platform) (Fello 2001).

The Murzuq Basin in southwest Libya is a massive Paleozoic intracratonic-sag basin with a ladle shape, covering more than $350,000 \mathrm{~km}^{2}$. It is sandwiched between the Gargaf arch to the north and the Tibesti-Haruj uplift to the east, as well as to the southwest by the Precambrian Logger Massif of Algeria and Niger (Fig. 1). The basin is mainly filled with Paleozoic continental and marine sediments, with some Mesozoic and Cenozoic marine sediments. Murzuq Basin has several concessions with oil fields. In each field, some wells have been drilled to evaluate the hydrocarbon potential of the Cambro-Ordovician section described in 
Fig. 1 Map of Libya showing its major sedimentary basins and the location of the $\mathrm{NC} 115$ Concession and its oilfields. The boundaries of the basins are redrawn after Fello (2001)

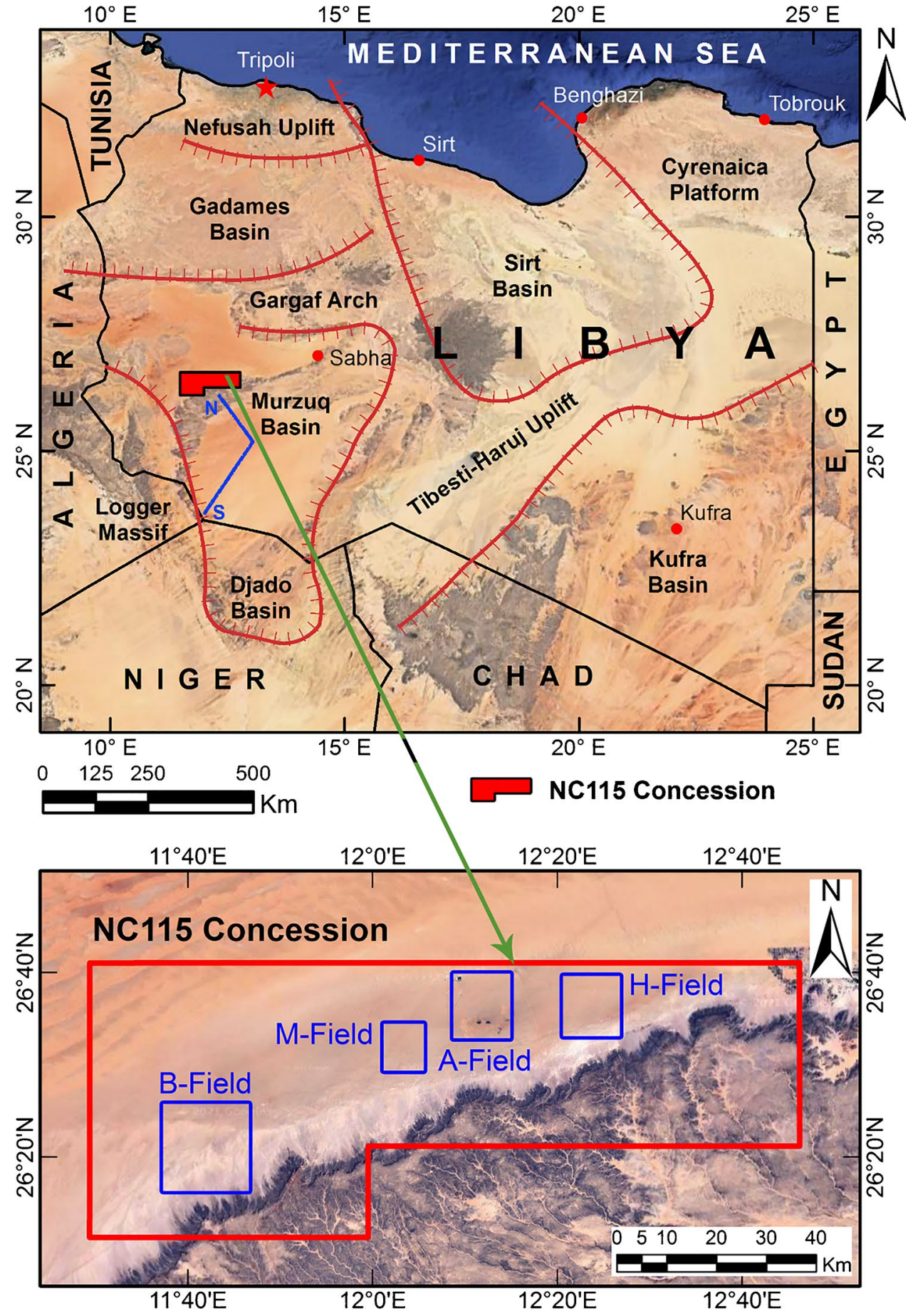

the stratigraphic column (e.g., Mohamed 2016; Selim et al. 2014). The "A" Oil Field is a part of the NC115 Concession, which is located on the Murzuq Basin's northwestern flank (Fig. 1). For this study, ten exploratory wells from the "A" Field were petrophysically analyzed.
The effectiveness of well-logging data in studying reservoir petrophysics has been demonstrated (Djebbar and Donaldson 2012). Well-logging data of the ten exploratory wells have been dedicated to define and evaluate the hydrocarbon potentialities of the Mamuniyat Formation 
in the "A" Oil Field. The logs were subjected to a thorough analytical formation evaluation in order to delineate the lithologic constituents, petrophysical parameters, and fluid saturation parameters. Open-hole well-logging data includes caliper, electric resistivity, spontaneous potential, density, sonic, neutron, and gamma ray logs, while lithological data are represented by composite logs. In this study, the Schlumberger's Interactive Petrophysics (IP) software was used.

\section{Geologic setting}

Figure 2 depicts a surface geological map of Murzuq Basin (Shalbak 2015). The stratigraphic succession of the basin and NC115 Concession, as well as their stratigraphic breaks according to the Repsol oil operations nomenclatures, is depicted in Fig. 3 (Fello 2001). The basin is underlain by Precambrian high-grade metamorphic and plutonic rocks and Infracambrian lowgrade metamorphic and unmetamorphic rocks of the Mourizdie Formation (Belaid et al. 2010). It is filled with a more than 3500-m-thick continental and marine sedimentary succession of Cambrian-Quaternary age (Thomas 1995).

The Upper Ordovician (Ashgillian) sandstones of the Mamuniyat Formation serve as the primary oil reservoir in the Murzuq Basin's oil fields, with the Lower Silurian hot shales of the Tanezzuft Formation serving as the primary source and seal (Fig. 4) (Hassan and Kendall 2014). Lithostratigraphically, Fello (2001) and Fello and Turner (2004) subdivided the Mamuniyat sandstone facies according to depositional environment into three members: lower, middle, and upper member. The lower member is dominated by a shallow marine coarsening-upward sandstone sequence; the middle is a
Fig. 2 Murzuq Basin surface geological map (after Shalbak 2015)

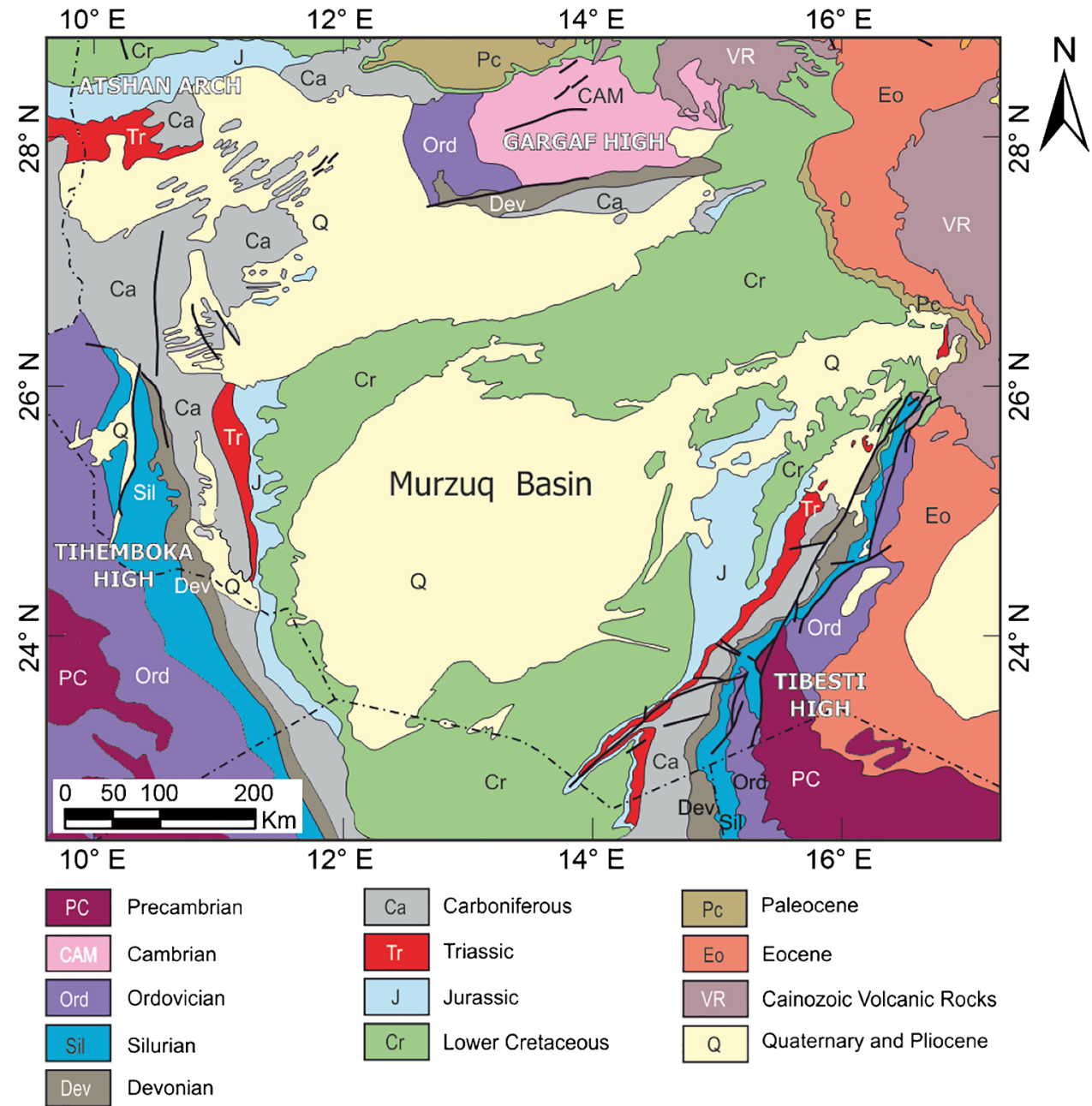


Fig. 3 Stratigraphic column of NC115 Concession, Murzuq Basin, Southwest Libya, and the major tectonic events affecting it (modified after Fello et al., 2001)

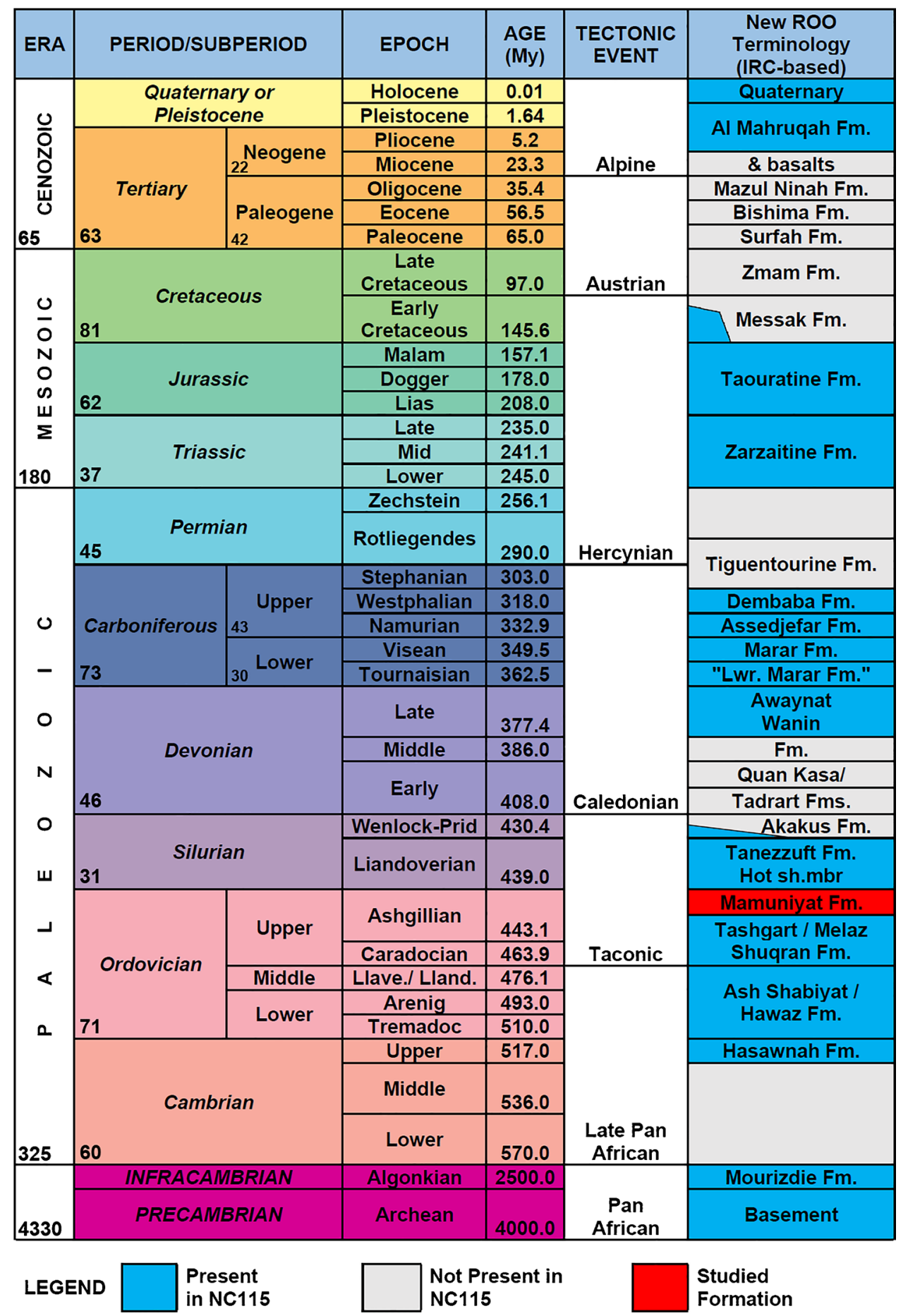

fining-upward marginal marine sequence dominated with radioactive black shales with fine- to medium-grained sandstones and coarse-grained siltstones; and the upper member is made up of coarsening-upward fluvial sandstone sequence.
The Taconic, Caledonian, Hercynian, Austrian, and Alpine tectonic events, particularly the Caledonian and Hercynian orogenies, have had a significant impact on the Murzuq Basin's tectonics and sedimentology (Belaid et al. 2010). They divided the basin into various uplifts and 
Fig. 4 North-south crosssection of Murzuq Basin (after Hassan and Kendall 2014). The location of the cross-section is plotted in Fig. 1

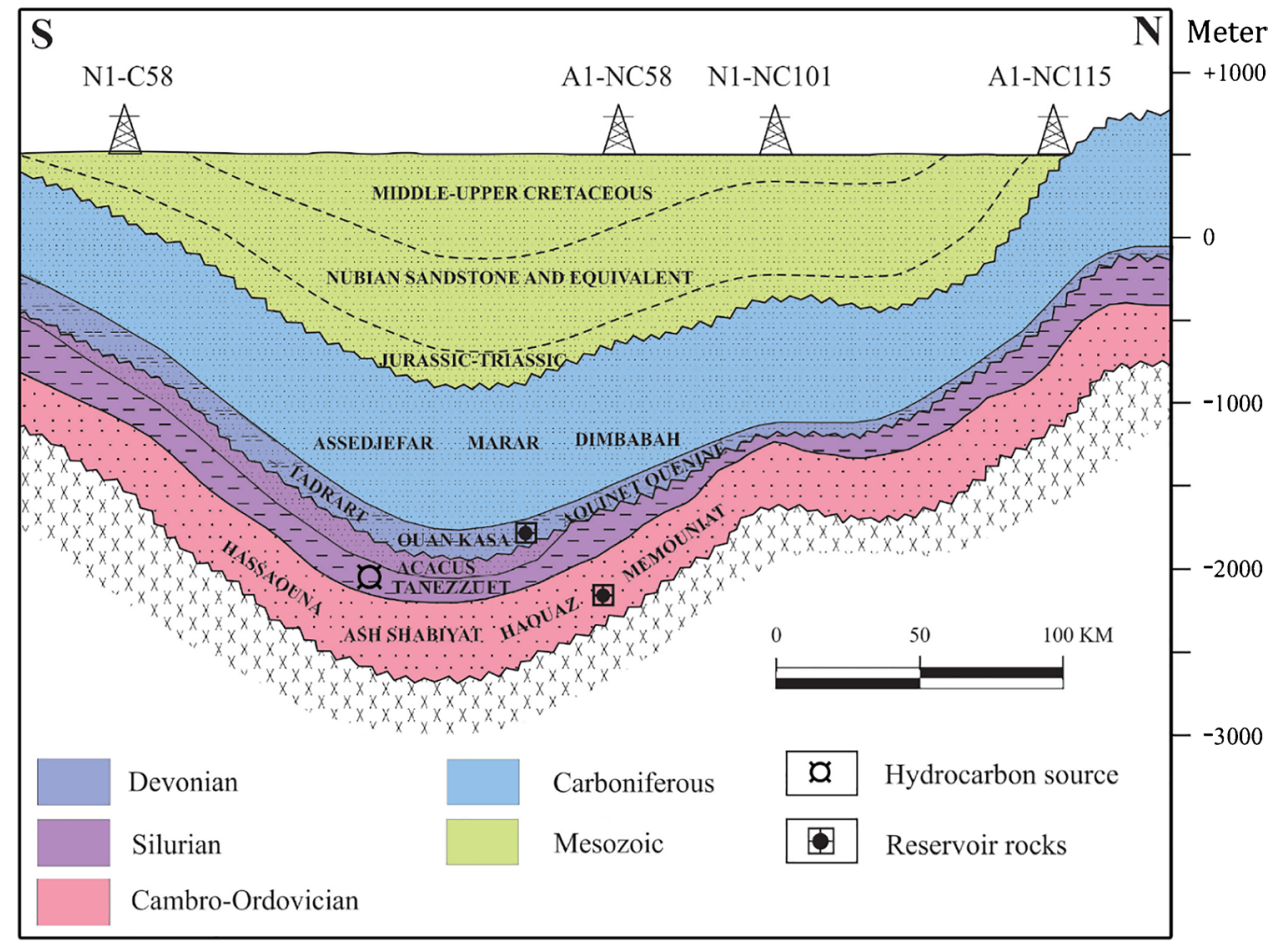

troughs of varying orientations, resulting in several major unconformities across the basin's sedimentary cover. The Caledonian tectonics caused a significant unconformity between Silurian and Devonian sequences. This unconformity reflects compressional tectonic movements that occurred during the Late Silurian to Early Devonian time (500-380 MA), when the main structural highs bounding the Murzuq Basin were reactivated (Davidson et al. 2000). It operated on an NW-SE axis (Klitzsch 1963) and resulted in the Silurian being overlooked along the Gargaf Arch in the basin's northern reaches (Fig. 2). The Hercynian compression caused by the Paleozoic collision of Gondwana and Laurasia affected the basin from the Late Carboniferous (Moscovian) to the Early Permian, spanning approximately 370 to 230 MA (Davidson et al. 2000). This event had a significant impact on Carboniferous sediment thickness where the Upper Carboniferous Tiguentourine Formation was lost due to erosion (Fig. 3). Aziz (2000) estimated a missing Carboniferous section in the NC115 block ranging from 1000 to $1800 \mathrm{~m}$. Hercynian tectonism was perpendicular to Caledonian tectonism, resulting in a series of horsts and grabens (Klitzsch 1963). The dominant fracture trends in the Murzuq Basin's southwest are the Caledonian NW-SE within the pre-Silurian sediments and the Hercynian NE-SW within the Silurian-Devonian rocks (Tawadros 2011; Shalbak 2015).

\section{Data analysis and processing}

The well-logging data for ten exploratory wells (Fig. 5) were obtained in analogue form and then divided into zones every 0.5 feet and converted to digital form for computer processing. The anomalous peaks in the data were removed and corrected, as well as the environmental effects such as mud filtrate, hole rugosity, bed thickness, and invasion effects were reduced. These data are empirically and analytically integrated to validate the necessary petrophysical properties and hydrocarbon potentialities of Mamuniyat sandstones in the "A" Oil Field. Table 1 contains a list of abbreviations used in this study.

The data were processed to derive some of the petrophysical parameters, such as cementation factor $(m)$, water resistivity $\left(R_{\mathrm{w}}\right)$, and matrix parameters $\left(\rho_{\mathrm{ma}}\right.$ and $\left.\Delta T_{\mathrm{ma}}\right)$, using cross-plots (e.g., Hingle and Pickett cross-plots), and then fed them into the IP software for evaluating the Mamuniyat reservoir. The petrophysical parameters were then calculated using IP software, as described by Serra (2007) and Mohamed (2016). The shale volume $\left(V_{\text {shale }}\right)$ was calculated using gamma ray log data. The weighted average neutron and density logs with shale correction were used to calculate porosity. The sonic $\log$ was used to calculate accurate primary porosity values. The connate water resistivity was then used to calculate the water saturation. The pay zone 


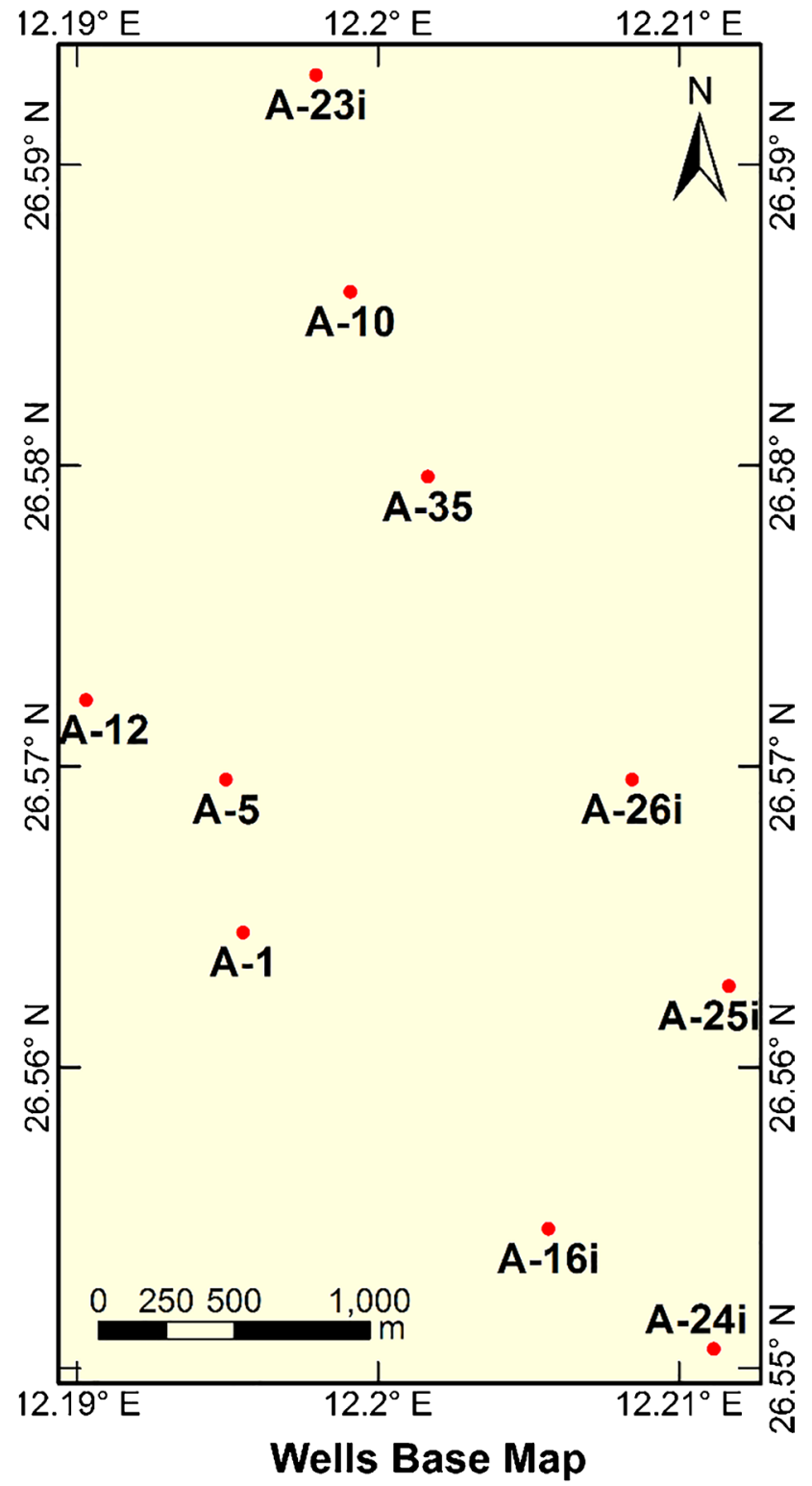

Fig. 5 Locations of the wells employed in this study

petrophysical sums and averages were calculated using a $V_{\text {shale }}$ cut-off of $38 \%$, a porosity cut-off of $9 \%$, and a $S_{\mathrm{w}}$ cutoff of 50\%. These cut-off percentages were determined by inspecting the porosity versus $V_{\text {shale }} \operatorname{logs}$ and cross-plots.

The input data set as well as the output results deduced from the well-logging parameters using the IP software were displayed in the vertical zone-wise litho-saturation crossplots. This is to assess the hydrocarbon potentialities of the formation based on the lithological and petrophysical parameters obtained from the IP software for each well separately. This plot is displayed in several tracks, as follows, from left
Table 1 List of the various abbreviations used in this study and their meanings

\begin{tabular}{ll}
\hline Abbreviation & Meaning \\
\hline$R_{\mathrm{w}}$ & Formation water resistivity \\
$R_{\mathrm{o}}$ & Resistivity of rock 100\% saturated with water \\
$R_{\mathrm{t}}$ & True resistivity of the formation and fluids \\
$S_{\mathrm{w}}$ & Formation water saturation \\
$\rho_{\mathrm{ma}}$ & Rock matrix density \\
$\Delta T_{\mathrm{ma}}$ & Matrix interval transit time \\
$\rho_{\mathrm{b}}$ & Bulk density \\
$V_{\text {shale }}$ & Fraction of shale in a sand formation \\
$\varnothing$ & Porosity \\
$\emptyset_{\mathrm{n}}$ & Neutron-derived porosity \\
$m$ & Cementation factor \\
$a$ & Tortuosity exponent \\
$n$ & Saturation exponent \\
\hline
\end{tabular}

to right: the first track contains logs of gamma ray, caliper, and spontaneous potential. It is followed by the horizon depths and tops in the second and third tracks, respectively. On the fourth track, there is a resistivity $\log$. In the fifth track, the porosity logs are displayed. The output results are depicted in the last two tracks, which represent the effective porosity, oil, and water saturation, as well as the lithological identification analysis obtained from the IP software. It should be noted that the Mamuniyat Formation under consideration is oil-bearing, with no gas.

\section{Analytical cross-plot technique}

The values of the matrix parameters $\left(\rho_{\mathrm{ma}}\right.$ and $\left.\Delta T_{\mathrm{ma}}\right)$ were calculated using Hingle's cross-plot, the oldest resistivity versus porosity cross-plot method. Figure 6 depicts a specific example for well A1. The top line represents the resistivity of water-filled rock $\left(R_{\mathrm{o}}\right)$ with $S_{\mathrm{w}}=1 . S_{\mathrm{w}}<1$ is represented by the other lines, which decrease clockwise. The intersection of the $R_{\mathrm{o}}$ line and the scale of the $x$-axis in porosity units determined the matrix parameters. The results showed that the average $\rho_{\mathrm{ma}}$ value is $2.66 \mathrm{gm} / \mathrm{cc}$ and the $\Delta T_{\mathrm{ma}}$ value is $55 \mu$ s/f. The points located between the lines $\left(S_{\mathrm{w}}=100 \%\right.$ and $S_{\mathrm{w}}=50 \%$ ) primarily represent water-bearing zones. The hydrocarbon-bearing zones have mostly been found below the $25 \%$ water saturation line. Pickett's cross-plot (Pickett 1966) is, on the other hand, another efficient common method to use. The true resistivity $\left(R_{\mathrm{t}}\right)$ is observed to be a function of porosity $(\varnothing)$, water saturation $\left(S_{\mathrm{w}}\right)$, and cementation factor $(m)$ in this technique (Fig. 7). In this study, it 
Fig. 6 Hingle cross-plot of Mamuniyat formation at A1-NC115

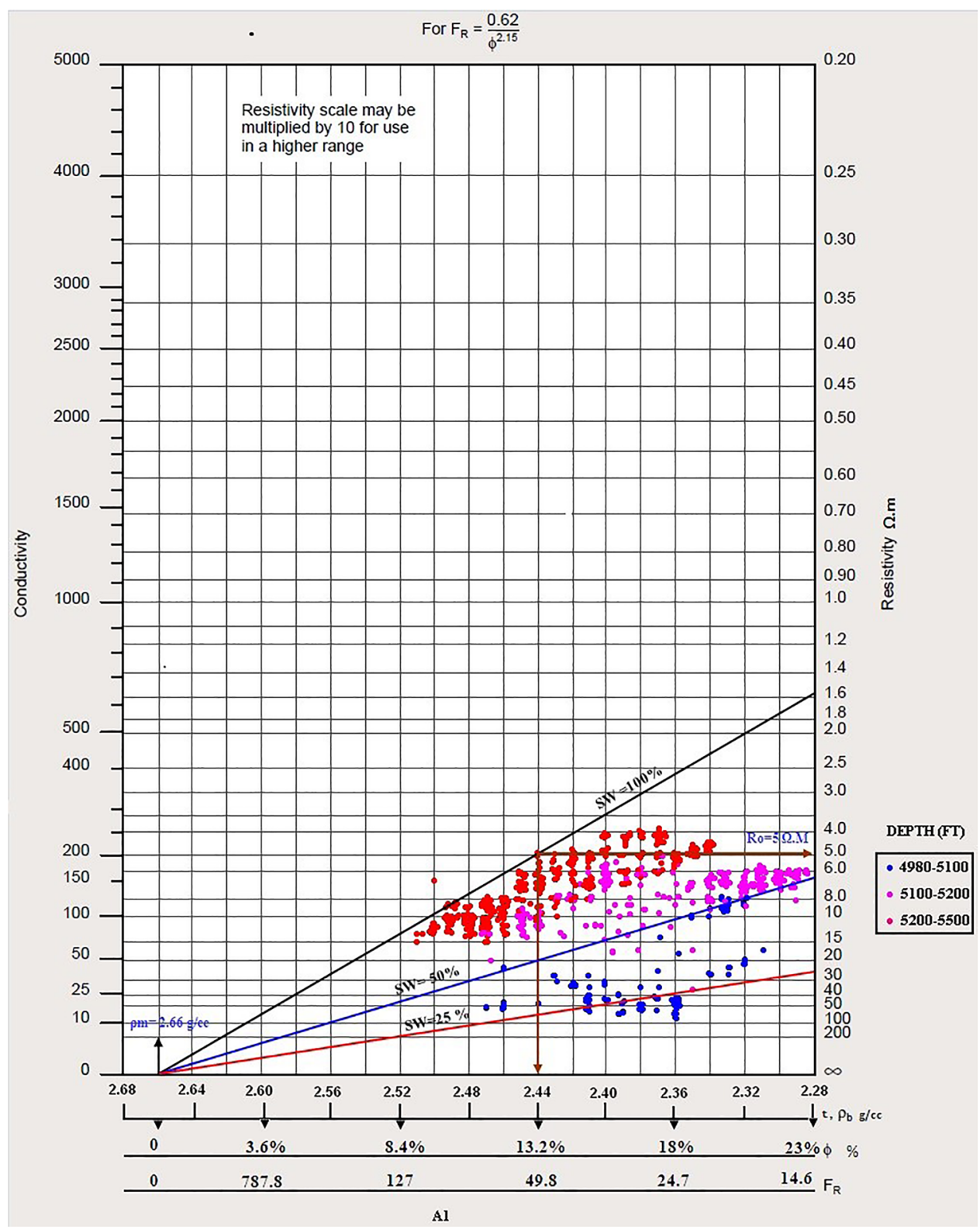

was used to help determine the formation water resistivity $\left(R_{\mathrm{w}}\right)$, water saturation, and cementation factor by plotting the porosity with deep resistivity values on two-by-three cycle $\log$-log paper.

At $100 \%$ water saturation, the intersection of $S_{\mathrm{w}}$ line with the horizontal axis represents a $* R_{\mathrm{w}}$. The crossplots revealed that the average value of $R_{\mathrm{w}}$ is $0.32 \Omega \cdot \mathrm{m}$, which is consistent with the core sample data obtained from the Repsol company (Selim et al. 2014). It was also discovered that the average value of $m$ was 1.9 (slope of $100 \% S_{\mathrm{w}}$ line), which is consistent with well-logging data. The average saturation exponent value $(n=1.75)$ was obtained directly from the cores obtained from the
Repsol company. The water-bearing zones represent the Mamuniyat Formation's lower part and are concentrated between lines $S_{\mathrm{w}} 100 \%$ and $25 \%$; on the other hand, the hydrocarbon-bearing zones represent the formation's upper part and are concentrated around the $25 \%$ water saturation line.

A dia-porosity $\rho_{\mathrm{b}} / \emptyset_{\mathrm{n}}$ cross-plot has been plotted for all wells to study the lithologic facies and their grain size analysis from well-logging data, revealing that the lithologic facies consist primarily of sandstones (Figs. 8 and 9). According to the relationship between porosity and water saturation, this sandstone is coursing upward from the lower to upper parts of the Mamuniyat reservoir (Fig. 10). The 
Fig. 7 Pickett plot for Mamuniyat Formation for A10-NC115 well, "A" Oil Field
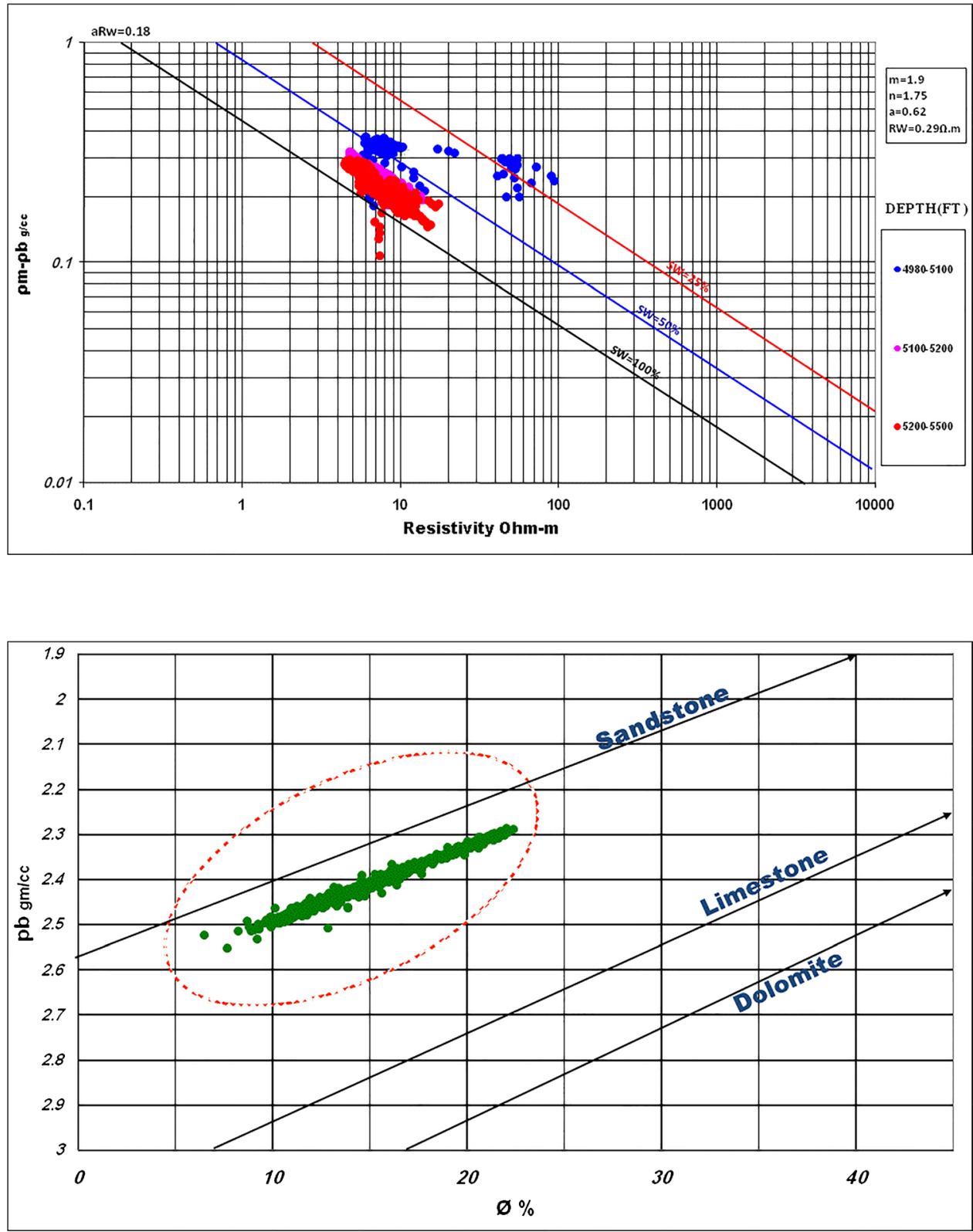

Fig. 8 A dia-porosity $\rho_{\mathrm{b}} / \emptyset_{\mathrm{n}}$ cross-plot for Mamuniyat Formation at well A5-NC115, "A" Oil Field information from well-logging data mentioned above were used as input parameters for the IP software to deduce the petrophysical parameters in the form of litho-saturation cross-plots, which will be discussed next.

\section{The litho-saturation analysis of Mamuniyat Formation}

The Mamuniyat Formation's petrophysical parameters have been calculated. The parameters considered include shale volume, porosity, and water and hydrocarbon saturations, which change from borehole to another. Their percentages have been discussed for a few selected wells for illustration purposes only, as follows:

The calculated shale volume varies from well to well, but a few intercalations are generally found. It ranges from 0.2 to $17.7 \%$ with a weighted value of $5.4 \%$ in well A1 (Fig. 11); effective porosity varies between 10.3 and $15.6 \%$ with a weighted value of $12.5 \%$, water saturation varies between 23.7 and $99.6 \%$ with a weighted value of $75 \%$, and oil saturation varies between 1 and $63.9 \%$ with a weighted value of $25 \%$. As shown in the litho-saturation cross-plot, the vertical distribution of these data shows that the Mamuniyat Formation's upper part is the most effective zone for hydrocarbon saturation (Fig. 11). 

cross-plot for Mamuniyat Formation at well A35-NC115, "A" Oil Field
Fig. 9 A dia-porosity $\rho_{\mathrm{b}} / \emptyset_{\mathrm{n}}$

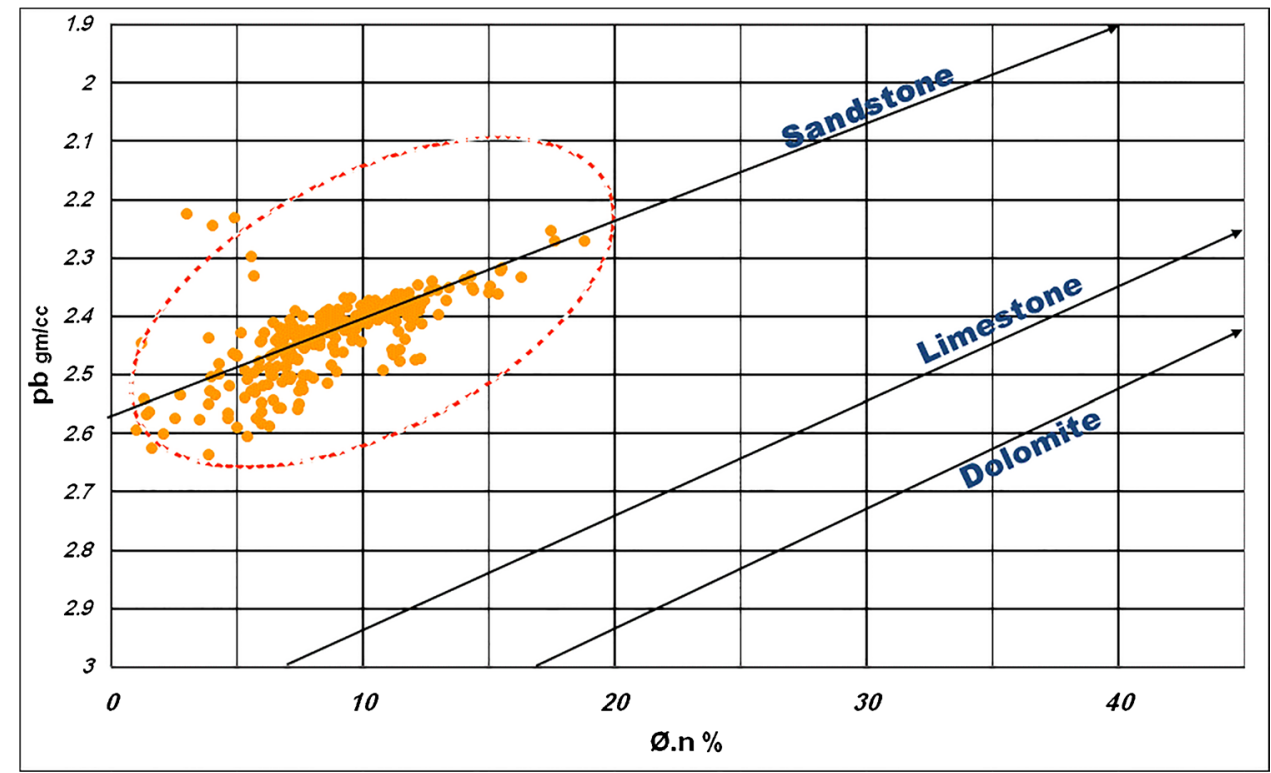

Fig. $10 S_{\mathrm{w}}$ vs $\emptyset$ showing upward coarsening sequence, for Mamuniyat Formation at A12-NC115, "A" Oil Field

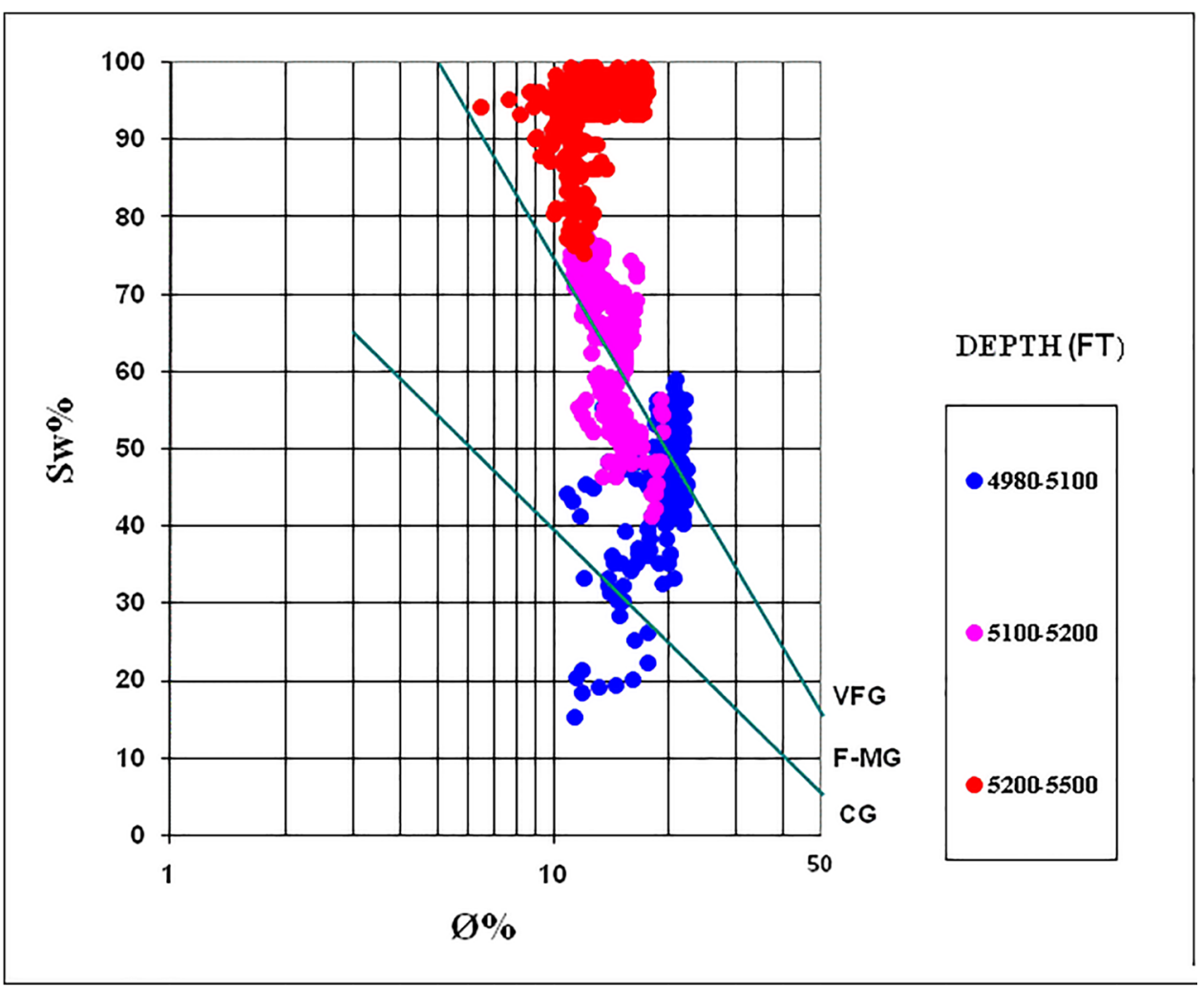

The determined shale volume of the well A10 (Fig. 12), on the other hand, varies between 0.1 and $4.5 \%$ with a weighted value of $1.3 \%$. The effective porosity varies between 5.5 and $18.3 \%$ with a weighted value of $13.5 \%$, the water saturation varies between 4 and $80 \%$ with a weighted value of $55 \%$, and the oil saturation varies between 7.3 and
$85 \%$ with a weighted value of $45 \%$. The litho-saturation cross-plot shows that the middle and lower parts of Mamuniyat are the most productive zones for hydrocarbon occurrence (Fig. 13).

While the litho-saturation cross-plot of well A24 reveals that the calculated shale volume varies between 0.1 and $12 \%$ 


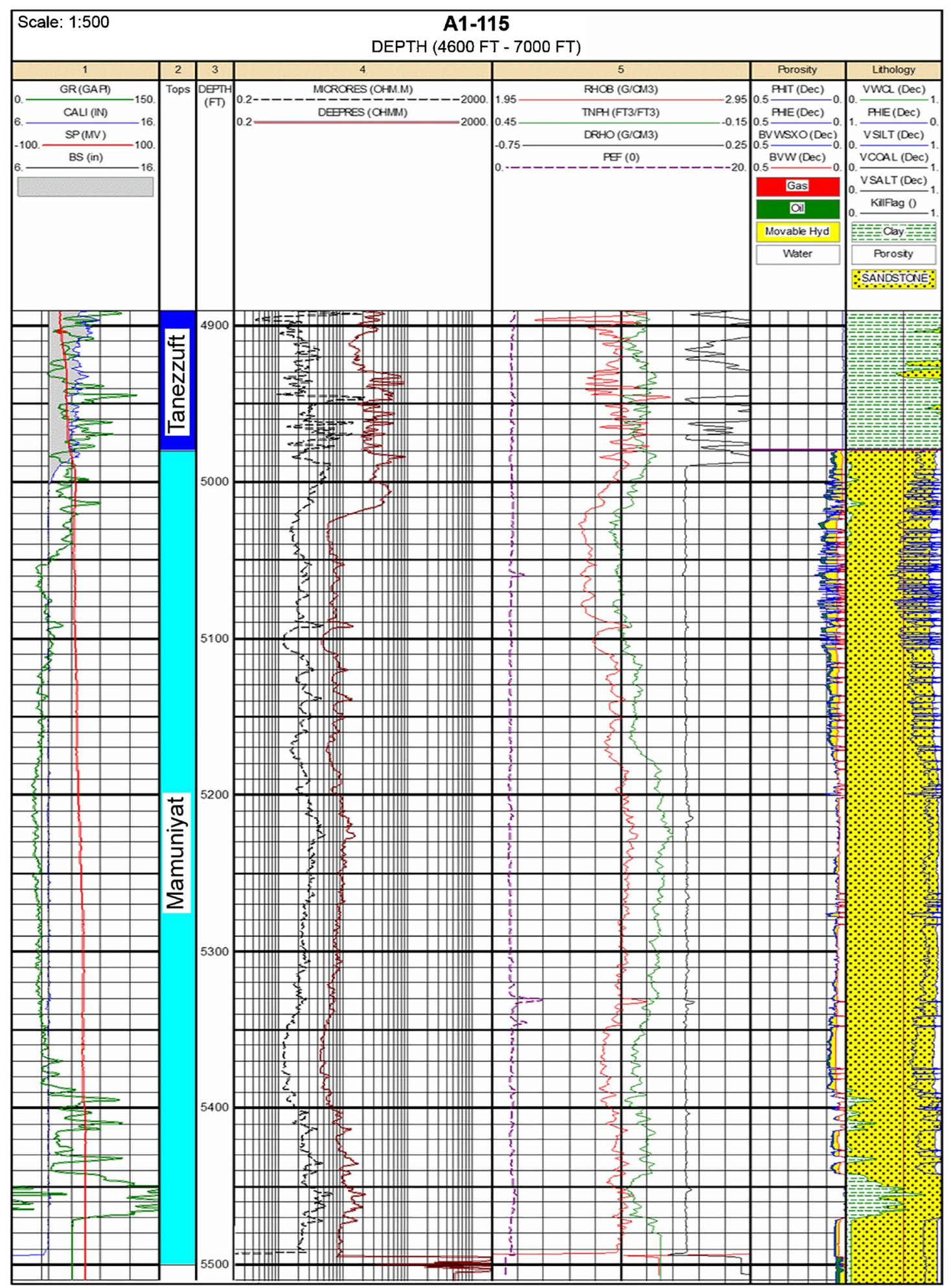

Fig. 11 Litho-saturation for Mamuniyat Formation, A1-NC115 well, "A" Oil Field

with a weighted value of $9 \%$, the effective porosity varies between 5.0 and $14 \%$ with a weighted value of $11.6 \%$, the water saturation varies between 3 and $44 \%$ with a weighted value of $40 \%$, and the oil saturation varies between 8 and $75 \%$, with a weighted value of $60 \%$. As shown in the lithosaturation cross-plot from the hydrocarbon potentiality, the 
middle part is the most effective zone for hydrocarbon content (Fig. 13). There is no evidence to differentiate the petrophysical parameters in one part of the Mamuniyat Formation from another; they vary from well to well but generally reflect good reservoir rocks. As shown in the litho-saturation cross-plot, the total thickness of the Mamuniyat reservoir varies from well to well, indicating that this field may be structurally controlled.

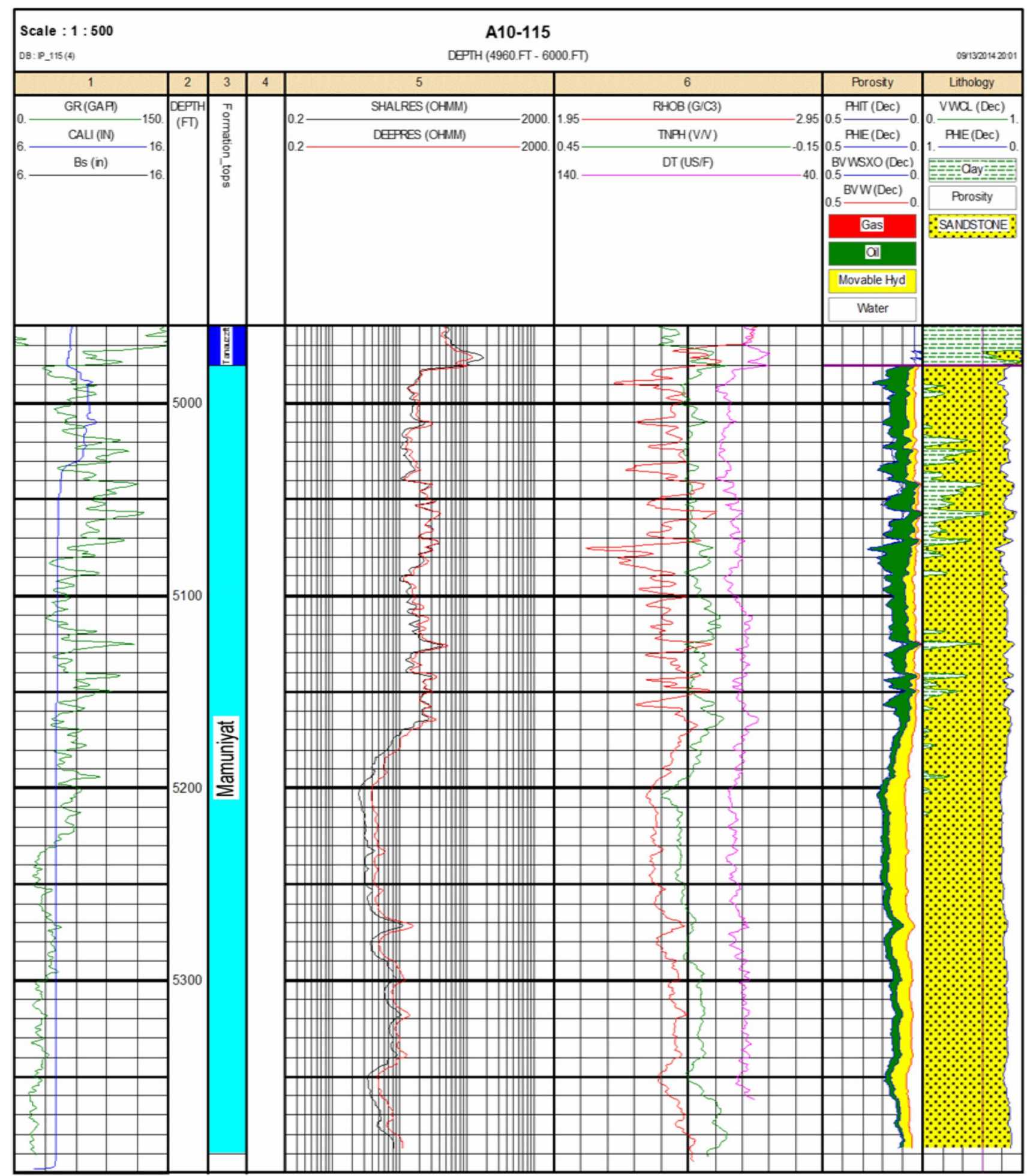

Fig. 12 Litho-saturation for Mamuniyat Formation, A10-NC115 well, "A" Oil Field 


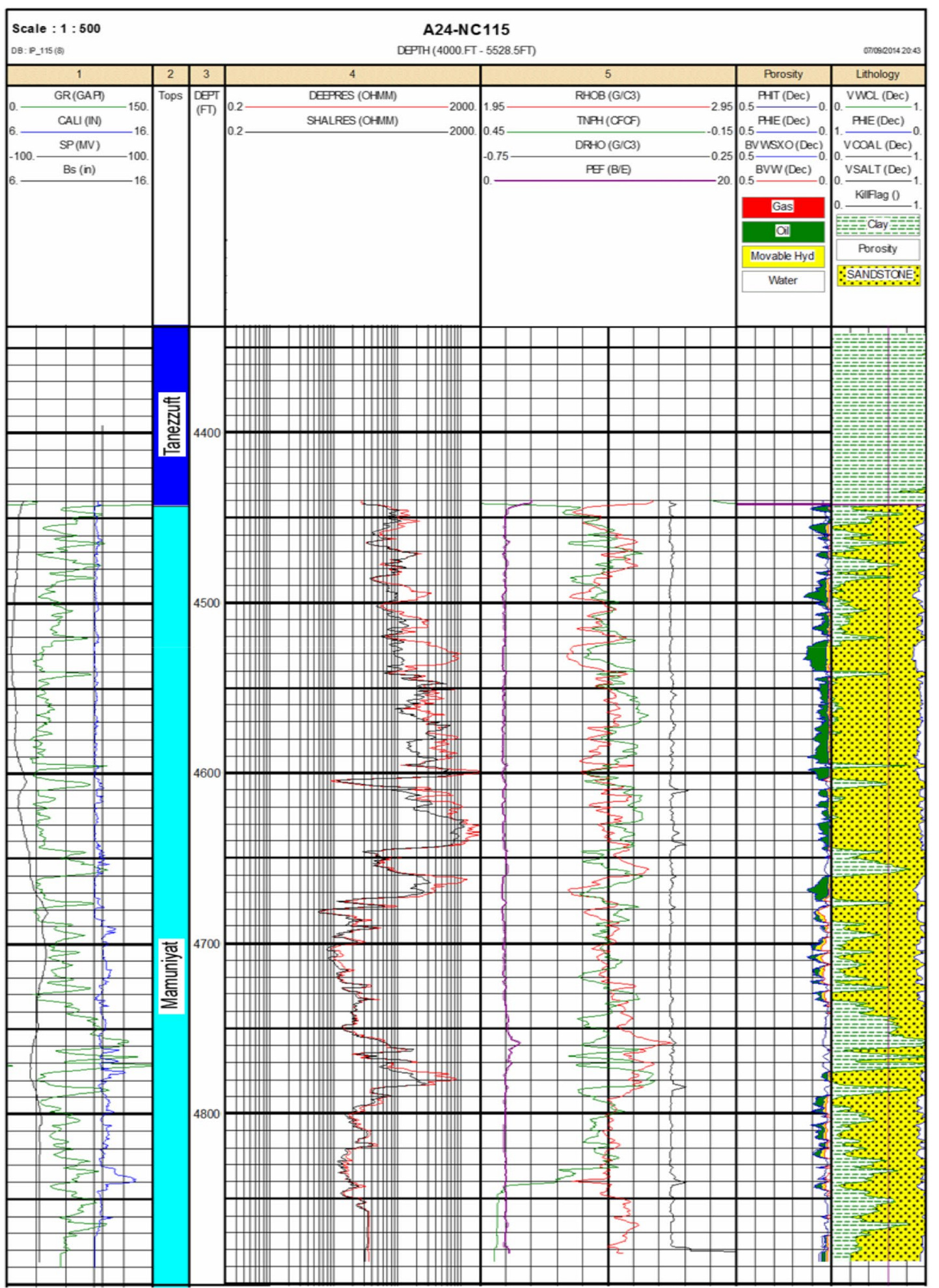

Fig. 13 Litho-saturation for Mamuniyat Formation, A24-NC115 well, "A" Oil Field

\section{Discussion}

The primary goal of this research is to investigate the petrophysical parameters and hydrocarbon potentials of the Mamuniyat Formation in the "A" Oil Field, NC115 Concession, Murzuq Basin. The oil is stored in the Ordovician Mamuniyat reservoir and sourced from the hot shales of the Silurian Tanezzuft Formation (Craik et al. 2001). 
Fig. 14 Distribution maps of the effective porosity (a) and oil saturation (b) in "A" Oil Field
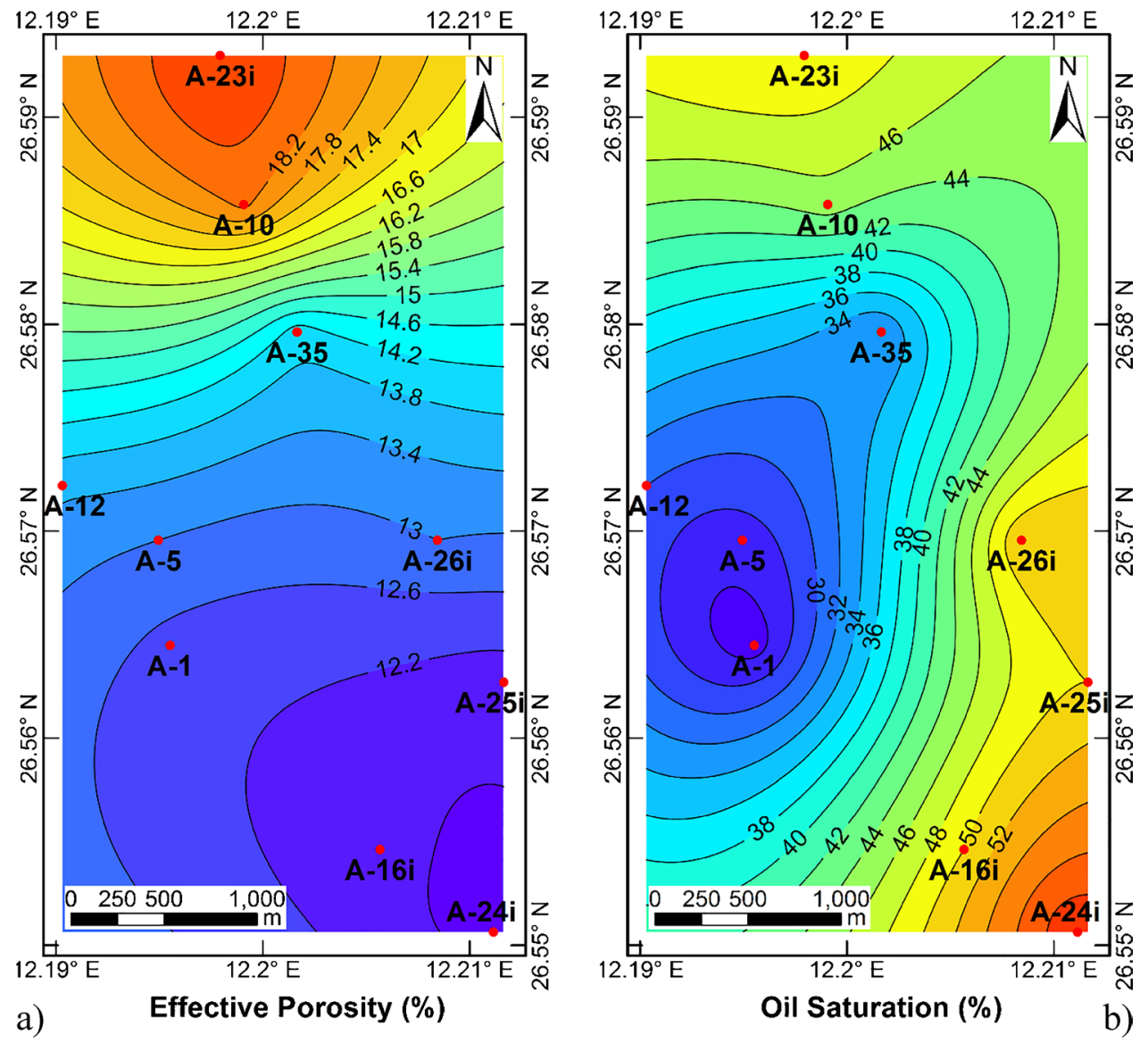

Ten exploratory wells have been chosen for this field. The cross-plot output results show lithological facies that are mostly sandstone with a little shale. This sandstone is coursing upward. Hingle's cross-plot was used to calculate the matrix parameters $\left(\rho_{\mathrm{ma}}\right.$ and $\left.\Delta T_{\mathrm{ma}}\right)$. The Pickett cross-plot, on the other hand, has been used to calculate $R_{\mathrm{w}}$ and $m$. The findings of these cross-plots are highly consistent with the findings of the core sample analysis. This agreement highlights the cross-plots' high reliance in the absence of core sample data. For each well, the dia-porosity $\rho_{\mathrm{b}} / \emptyset_{\mathrm{n}}$ cross-plots have been plotted. They stated that the lithologic facies is primarily composed of sandstones. Hingle's cross-plot revealed that the average values of $\rho_{\mathrm{ma}}$ and $\Delta T_{\mathrm{ma}}$ are $2.66 \mathrm{gm} / \mathrm{cc}$ and $55 \mu \mathrm{s} / \mathrm{f}$, respectively. Pickett cross-plots revealed that the average value of $R_{\mathrm{w}}$ is $0.32 \Omega \cdot \mathrm{m}$. All of the above-mentioned parameters are consistent with those derived from the core sample data collected by the Repsol Oil Operation. The calculated petrophysical parameters show a valuable reservoir because the weighted effective porosity values reached up to $19 \%$, which is relatively high. At well A23i, effective porosity values generally increase northward (Fig. 14a). Furthermore, the weighted values of hydrocarbon saturation percentages have a maximum value of $60 \%$, which increases toward the north at well A23i and to the south east at well A24i (Fig. 14b). The low shale volume reflects the high quality of this reservoir. The welllogging data and calculated petrophysical parameters indicate that this reservoir is primarily oil-bearing, with some sandstone levels saturated with water.

Funding Open access funding provided by The Science, Technology \& Innovation Funding Authority (STDF) in cooperation with The Egyptian Knowledge Bank (EKB).

\section{Declarations}

Conflict of interest The authors declare no competing interests.

Open Access This article is licensed under a Creative Commons Attribution 4.0 International License, which permits use, sharing, adaptation, distribution and reproduction in any medium or format, as long as you give appropriate credit to the original author(s) and the source, provide a link to the Creative Commons licence, and indicate if changes were made. The images or other third party material in this article are included in the article's Creative Commons licence, unless indicated otherwise in a credit line to the material. If material is not included in the article's Creative Commons licence and your intended use is not permitted by statutory regulation or exceeds the permitted use, you will need to obtain permission directly from the copyright holder. To view a copy of this licence, visit http://creativecommons. org/licenses/by/4.0/. 


\section{References}

Aziz A (2000) Stratigraphy and hydrocarbon potential of the Lower Palaeozoic succession of License NC-115, Murzuq Basin, SW Libya. In: Sola MA, Worsley D (eds) Geological Exploration in Murzuq Basin. Elsevier Science B.V, Amsterdam, pp 349-368

Belaid A, Krooss BM, Littke R (2010) Thermal history and source rock characterization of a Paleozoic section in the Awbari Trough, Murzuq Basin, SW Libya. Marine Pet Geol 27(3):612-632. https://doi.org/10.1016/j.marpetgeo.2009.06.006

Craik D, Quesada S, Lemaire R, Odriozola A, Bolatti N (2001) Sistema petrolero Tanezzuf-Mamuniyat. Cuenca Murzuq, Libia: Boletın Inf Pet 68:97-108

Davidson L, Beswetherick S, Craig J, Eales M, Fisher A, Himmali A, ... Smart J (2000) The structure, stratigraphy and petroleum geology of the Murzuq Basin, Southwest Libya. In: Sola MA, Worsley D (eds) Geological Exploration in Murzuq Basin. Elsevier Science B.V, Amsterdam, pp 295-320

Djebbar T, Donaldson EC (2012) Theory and practice of measuring reservoir rock and fluid transport properties (3rd ed., pp. 976): Gulf Professional Publishing

Fello NM (2001) Depostional environments, diagenesis and reservoir modelling of Concession NC115, Murzuq Basin, SW Libya. (PhD Thesis), Durham University

Fello NM, Turner B (2004) Depositional environments of the Upper Ordovician Mamuniyat Formation, NW Murzuq Basin, Libya.
Paper presented at the Proceedings of 3rd International Symposium on Geophysics, Tanta

Hassan HS, Kendall CC (2014) Hydrocarbon provinces of Libya: a petroleum system study. In: Marlow L, Kendall C, Yose L (eds) Petroleum systems of the Tethyan region: AAPG Memoir 106 (pp. 101-141)

Klitzsch E (1963) Geology of the North-East flank of the Murzuk basin (Djebel ben Ghnema-Dor el Gussa area). Rev Inst Fr Petrol 18(10):1411-1427

Mohamed AK (2016) Reservoir quality of Hawaz Formation, J oil field, Concession NC186, NW Murzuq basin, SW Libya. Arab J Geosci 9(2):110. https://doi.org/10.1007/s12517-015-2037-7

Pickett GR (1966) A review of current techniques for determination of water saturation from logs. J Petrol Technol 18(11):1425-1433. https://doi.org/10.2118/1446-pa

Selim ESI, Kamel A, Kashlaf A (2014) Hydrocarbon probability of Middle Ordovician Hawaz Formation, Murzuq Basin, Southwestern Libya. Arab J Geosci 8(8):5531-5560. https://doi.org/10.1007/ s12517-014-1633-2

Serra O (2007) Well-logging and reservoir evaluation (pp. 250): Editions Technip, Paris

Shalbak FA (2015) Palaeozoic petroleum systems of the Murzuq Basin, Libya. (PhD Thesis), Universitat de Barcelona

Tawadros E (2011) Geology of North Africa (pp. 930): CRC Press.

Thomas D (1995) Geology, Murzuk oil development could boost SW Libya prospects. Oil Gas J U S 93(10):41-46 